\title{
Antibacterial and Antifungal Efficacy of Partially Partitioned Fractions of Spondias mombin (Linn) Extracts (Root, Leaf and Stem Bark) against Clinical and Environmental Isolates
}

\author{
Oludare Temitope Osuntokun ${ }^{1 *}$, Idowu TO $^{2}$ and Gamberini Maria Cristina ${ }^{3}$ \\ ${ }^{1}$ Department of Microbiology, Faculty of Science, Adekunle Ajasin University, Akungba Akoko, PMB 001, Ondo State, Nigeria \\ ${ }^{2}$ Department of Pharmaceutical Chemistry, Obafemi Awolowo University, Nigeria \\ ${ }^{3}$ Department of Life Sciences, University of Modena and Reggio Emilia, via G. Campi 103, 41125 Modena, Italy
}

\begin{abstract}
The purpose this research work is to determine the antibacterial and antifungal assay of partitioned fractions of S. mombin (Linn) extracts against clinical and environmental isolates. The root, leaf and stem-bark of S. mombin were harvested and air-dried. The dried S. mombin was milled into powdered form using manual grinder. Powdered S. mombin $(1 \mathrm{~kg})$ each of the different S. mombin parts was extracted with $3 \mathrm{~L}$ of $70 \%(\mathrm{v} / \mathrm{v})$ ethanol, ethyl acetate and distilled water for $72 \mathrm{~h}$ at room temperature. The SMRE and SMREA were used to code for root part; SMLE and SMLEA for the leaf part; and SMSBE and SMSBEA for the stem-bark part, each was fractionated on column chromatography with silica as the stationary phase using $n$-hexane, ethyl acetate and ethanol as the eluting solvent to obtain $n$-hexane, ethyl acetate and ethanol fractions. Antimicrobial and antifungal screened was observed using agar well diffusion test. The result obtained showed that in partially purified ethyl acetate leaf extracts, Fraction $\left(F_{1}\right.$ SMLEAH) showed significant inhibitory effect $(p \leq 0.05)$ on all the test bacteria, except Klebsiella pneumoniae and Salmonella typhi at concentrations of $20.0-2.5 \mathrm{mg} / \mathrm{ml}$, Fraction $\left(F_{2} S M L E A E A\right)$ was not effective against Salmonella cholleraesuis, B. substilis, Citrobacter koseri and Salmonella typhi. Fraction ( $F_{3}$ SMLEAE) showed little or no inhibitory effect on most of the bacteria at all the concentration used. It can be deduced that in partially purified ethanolic leaf extracts, Fraction $\left(F_{1} S M L E H\right)$ showed inhibitory effect on Burkholderia cepacia. All the organisms

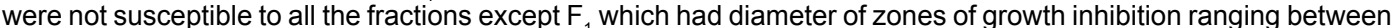
4.0-1.0 mm at $5 \mathrm{mg} / \mathrm{ml}-0.625 \mathrm{mg} / \mathrm{ml}$ on Mycobacterium abscessus. Partially purified ethanolic stem bark extracts, antifungal activity of the partially purified ethanolic extracts of $S$. mombin, Fractions $\left(F_{1}\right.$ SMLEH, $\left.F_{2} S M L E E A\right)$ and $\mathrm{F}_{3}$ SMLEE), significant antifungal activity $(\mathrm{p} \leq 0.05)$ was observed at $20.0 \mathrm{mg} / \mathrm{ml}$ with most test fungi. Trichoderma horizionum was not susceptible to all the three fractions, while Aspergillus niger and Syncephala strumracemosum were susceptible to only fraction $\left(F_{2}\right.$ SMLEEA). Fractions $\left(F_{1}\right.$ SMSBEH, $F_{2}$ SMSBEEA), $F_{3}$ SMSBEE) on the test as the eluting solvent. Significant inhibitory effect $(p \leq 0.05)$ was observed in all the fractions at $20 \mathrm{mg} / \mathrm{ml}$ against most of the test bacteria. While, zones of growth inhibition of the various fractions varied with the test bacteria with the highest diameter zone of $8.0 \mathrm{~mm}$ recorded in fraction $F_{1}$ against Salmonella typhi. Fractions $\left(F_{2} S M S B E E A\right.$ and $\mathrm{F}_{3}$ SMSBEE) possessed significant inhibitory effect $(\mathrm{p} \leq 0.05)$ at $20.0-5.0 \mathrm{mg} / \mathrm{ml}$ on the test fungi, except Candida kruise and Rhizopus stonifer. The plant part by solvent interactive effect was significant $(p<0.05)$, suggesting that the MICs and MBCs of test bacteria were observed at 0.3125 and $0.1562 \mathrm{mg} / \mathrm{ml}$ and MICs and MFCs test fungal were observed at 0.3125 and $0.1562 \mathrm{mg} / \mathrm{ml}$ respectively, The various plants differ significantly according to extraction solvent, These findings demonstrate the possible effectiveness of the $S$. mombin plant, especially its stem bark extracts, in treating microbial infections.
\end{abstract}

Keywords: Antibacterial; Antifungal assay; Partitioned fractions; Spondias mombin; Environmental isolates; Agar well diffusion

\section{Introduction}

The plant Spondias mombin (Linn) also called yellow mombin in English, Igongo/Ichankla in Idoma, and Uchakuru in Igbo, is common in the forest and savanna regions of Nigeria. It is used in several countries of the world to treat various ailments including infectious diseases. Spondias mombin (Linn) is a small tree that grows up to $20 \mathrm{~m}$ (60 ft.) high and $1.5 \mathrm{~m}$ (5 ft.) in girth, moderately buttressed; bark thick, corky, deeply fissured, slash pale pink, darkening rapidly, branches low, branchlets glabrous; leaves pinnate, leaflets 5-8 opposite pairs with a terminal leaflet. It belongs to the family Anacardiaceae. The roots are used as febrifuge in Ivory Coast and the bark is used as a purgative and in local applications for leprosy. The bark decoction is also used in the treatment of severe cough. It serves as an emetic, a remedy for diarrhea, dysentery, hemorrhoids and a treatment for gonorrhea and leucorrhea [1]. The decoction of the astringent bark is believed to expel calcifications from the bladder. A report showed that the bark contains a certain amount of tannin and this explains the reason why the dry pulverized bark is applied as a dressing to a wound [1].
A decoction of the young leaves is a remedy for diarrhea and dysentery and the juice of crushed leaves and the powder of dried leaves are used as poultices on wounds and inflammations. The gum is employed as an expectorant and to expel tapeworms [2]. A leaf infusion is a common cough remedy or used as a laxative for fever with constipation and leaf decoction is used in treatment of gonorrhea. The leaves are used for fresh wounds to prevent inflammation. A decoction of pounded leaves of $S$. mombin is used as an eye lotion and the juice

*Corresponding author: Oludare Temitope Osuntokun, Department of Microbiology Faculty of Science, Adekunle Ajasin University, Akungba Akoko, PMB 001, Ondo State, Nigeria, Tel: +2347057890597; E-mail: osuntokun4m@yahoo.com

Received January 20, 2018; Accepted January 27, 2018; Published January 31, 2018

Citation: Osuntokun OT, Idowu TO, Cristina GM (2018) Antibacterial and Antifungal Efficacy of Partially Partitioned Fractions of Spondias mombin (Linn) Extracts (Root, Leaf and Stem Bark) against Clinical and Environmental Isolates. Med Chem (Los Angeles) 8: 010-017. doi: 10.4172/2161-0444.1000490

Copyright: () 2018 Osuntokun OT, et al. This is an open-access article distributed under the terms of the Creative Commons Attribution License, which permits unrestricted use, distribution, and reproduction in any medium, provided the original author and source are credited. 
Citation: Osuntokun OT, Idowu TO, Cristina GM (2018) Antibacterial and Antifungal Efficacy of Partially Partitioned Fractions of Spondias mombin (Linn) Extracts (Root, Leaf and Stem Bark) against Clinical and Environmental Isolates. Med Chem (Los Angeles) 8: 010-0017. doi: $10.4172 / 2161-0444.1000490$

pressed from young, warm leaves is given to children for stomach troubles. The extract has shown anti-inflammatory activity in Wister rats [3]. A tea made from the flowers and leaves is taken to relieve stomach ache, biliousness, and urethritis, cystitis and eye and throat inflammations. A decoction of the root is used as purgative $[3,4]$.

\section{Materials and Methods}

\section{Collection of plant materials}

The root, leaf, and stem bark of Spondias mombin tree were harvested early in the morning into a polythene bag at Oja Oba market, Ikare Akoko, Ondo State, a tropical rainforest of Ondo State, Nigeria with latitude (7.21692 North) and longitude (5.21561 East). The plant was authenticated at the herbarium of the Department of Pharmaceutical chemistry, Obafemi Awolowo University, Ile -Ife, Osun State, Nigeria and voucher was deposited. A voucher number was issue at the herbarium for proper documentation (DPC-SPM 0340).

\section{Preparation and extraction of Spondias mombin plant}

The root, leaf and stem-bark of Spondias mombin plant were harvested and air-dried. The dried leaves were milled into powdered form using manual grinder. Powdered plant material $(1 \mathrm{~kg})$ each of the different plant parts was extracted with $3 \mathrm{~L}$ of $70 \%$ (v/v) ethanol, ethyl acetate and distilled water for $72 \mathrm{~h}$ at room temperature. The extraction process was repeated four times until the extract became clear. The filtrates were combined and concentrated under reduced pressure Rotatory Evaporator at $35^{\circ} \mathrm{C}$ to give, SMRE, SMREA and SMRAQ for root part; SMLE, SMLEA and SMLAQ for the leaf part; and SMSBE, SMSBEA and SMSBAQ for the stem-bark part. The dry extracts were kept in tightly stoppered bottles in a refrigerator at $20^{\circ} \mathrm{C}$ for further analysis.

\section{Column fractionation of various crude extracts of the different plant parts}

The SMRE and SMREA from root part; SMLE and SMLEA for the leaf part; and SMSBE and SMSBEA for the stem-bark part each was fractionated on column chromatography with silica as the stationary phase using $n$-hexane, ethyl acetate and ethanol as the eluting solvent to obtain $n$-hexane, ethyl acetate and ethanol fractions for each and coded as SMREH, SMREEA and SMREE for the ethanol extract of the root and SMREAH. SMREAEA and SMREAE represent the different fractions for the ethyl acetate extract of the root. On the other hand, SMLEH, SMLEEA and SMLEE for the ethanol extract of the leaf while SMLEAH, SMLEAEA and SMLEAE for the ethyl acetate extract of the leaf. SMSBEH, SMSBEEA and SMSBEE for the ethanol extract of the stem-bark and SMSBEAH. SMSBEAEA and SMSBEAE for the ethyl acetate extract of the stem-bark.

\section{Preparation of different concentrations of extracts}

Spondias mombin extracts (root, leaf and stem bark) (0.6 g) were weighed separately into a sterile bottle and reconstituted in $2.5 \mathrm{ml}$ of Dimethyl surfoxide (DMSO) after which $7.5 \mathrm{ml}$ of sterile distilled water was added to make up $10 \mathrm{ml}(60 \mathrm{mg} / \mathrm{ml})$ in total. Then $3 \mathrm{ml}$ of the reconstituted extract was dispensed into another bottle containing $3 \mathrm{ml}$ of sterile distilled water to make up $6 \mathrm{ml}(30 \mathrm{mg} / \mathrm{ml})$. The same procedure was repeated for $15 \mathrm{mg} / \mathrm{ml}$ and $7.5 \mathrm{mg} / \mathrm{ml}$ respectively [5].

\section{Antimicrobial assay of Spondias mombin extracts}

The antimicrobial activities of the Spondias mombin extracts were assessed on the test organisms. The test bacteria and fungi were selected on the basis of the diseases against which Spondia mombim was used.
The antibacterial assay of the extracts was repeated by the agar well diffusion method [6].

Antibacterial assay of partitioned fractions of Spondias mombin extracts (root, leaf, and bark): The antimicrobial assay of partitioned fractions of Spondias mombin extracts on the test bacteria was carried out by the agar diffusion method [6]. A $0.1 \mathrm{ml}$ of 1:10,000 dilutions (equivalent to $10^{6} \mathrm{cfu} / \mathrm{ml}$ ) of fresh overnight broth culture of the test bacteria was seeded on molten Mueller-Hinton agar plate. Using a sterile corn borer of $6 \mathrm{~mm}$ diameter, equidistant wells was made in the agar. One millimeter of the various re-suspended extracts $(7.5,15,30$ and $60 \mathrm{mg} / \mathrm{ml}$ ) was introduced into the wells. The plates were allowed to stand on the bench for 1 hour, to allow pre-diffusion of the extracts before incubation. The plates were then incubated at $37^{\circ} \mathrm{C}$ for 24 to 48 hours. The zones of inhibition were measured to the nearest millimeter $(\mathrm{mm})$ using a transparent ruler (NCCLS).

Antifungal assay of partitioned fractions of Spondias mombin extracts (root, leaf, and stem bark): Antifungal assay of partitioned fractions of the root, leaf, and stem bark of Spondias mombin extracts was done using Agar well diffusion method. A 5-day old fungal culture on potato dextrose agar (PDA) was flooded with $2 \mathrm{ml}$ of sterile distilled water containing $3 \%$ glycerol. The spores were harvested by scraping with a sterile inoculating loop. Sterile PDA plates were inoculated with $0.1 \mathrm{ml}$ of the fungal spore suspension using the spread plate technique. Five wells were bored on the potato dextrose agar (PDA) plates using a $6 \mathrm{~mm}$ sterile corn borer. The first, second, third and fourth well were filled with $60,30,15$ and $7.5 \mathrm{mg} / \mathrm{ml}$ of the extracts, respectively, The plates were allowed to stand on the bench for 1 hour before incubating at $25^{\circ} \mathrm{C}$ for 5 days. Diameter of zones of growth inhibition was then measured in millimeter with a vernier caliper [7].

Determination of minimum inhibitory concentration (MIC) partitioned fractions of Spondias mombin extracts (root, leaf, and stem bark)

A serial dilution of the extracts ranging from 1:10 to 10.009 was made. The bacterial strain was cultured in Muller Hinton broth and suspended in $5 \mathrm{ml}$ peptone water. To the suspension, $5 \mathrm{ml}$ of each extract concentration was added into Muller Hinton broth and then $1.0 \mathrm{ml}$ of standardized broth culture containing $1.0 \times 10^{6} \mathrm{cfu} / \mathrm{ml}$ was introduced into each test tube and then incubated at $37^{\circ} \mathrm{C}$ for $18-24$ hrs. Following incubation, turbidity was examined; the concentration at which no turbidity was observed was regarded as the MIC value [8].

Determination of minimum bactericidal concentration (MBC) of partitioned fractions of Spondias mombin extracts (roots, leaf, and stem bark)

Suspensions from the MICs were used for the MBC determination. A bacterial streaking of equal streaks was made from the MIC test tubes onto Mueller-Hinton agar plates and the procedure was repeated all through the required numbers of the corresponding isolates. The isolated organism on the Mueller-Hinton agar was incubated at $37^{\circ} \mathrm{C}$ for $18-24$ hrs. After incubation, the plates were observed; the concentration that exhibited no bacterial growth was considered as the MBC [8].

\section{Results}

The antibacterial activity of partially purified ethyl acetate leaf extracts of Spondias mombin

Tables 1 and 2 shows the antibacterial activity of partially purified 
Citation: Osuntokun OT, Idowu TO, Cristina GM (2018) Antibacterial and Antifungal Efficacy of Partially Partitioned Fractions of Spondias mombin (Linn) Extracts (Root, Leaf and Stem Bark) against Clinical and Environmental Isolates. Med Chem (Los Angeles) 8: 010-0017. doi: $10.4172 / 2161-0444.1000490$

\begin{tabular}{|c|c|c|c|c|c|c|c|c|c|c|c|c|c|c|c|c|c|c|c|c|c|c|c|c|}
\hline \multicolumn{10}{|c|}{ Fraction $\mathrm{F}_{1}$ (SMLEAH) } & racti & $F_{2}($ & MLE & & & \multicolumn{10}{|c|}{ Fraction $F_{3}($ SMLEAE) } \\
\hline \multicolumn{25}{|c|}{ Diameter of zones of inhibition $(\mathrm{mm})$} \\
\hline Bacteria & 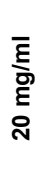 & $\begin{array}{l}\bar{\xi} \\
\stackrel{ }{E} \\
\end{array}$ & 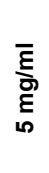 & $\begin{array}{l}\bar{\xi} \\
\text { छ } \\
\text { مٌ }\end{array}$ & 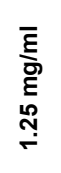 & 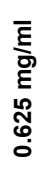 & 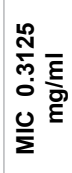 & 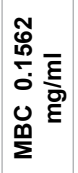 & $\begin{array}{l}\bar{\Xi} \\
\text { ڤે } \\
\text { నิ }\end{array}$ & $\begin{array}{l}\bar{\xi} \\
\stackrel{5}{\xi} \\
\stackrel{5}{\circ}\end{array}$ & 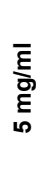 & 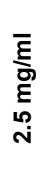 & 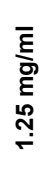 & $\begin{array}{l}\bar{\xi} \\
\bar{్} \\
\underline{్} \\
\stackrel{0}{0} \\
0\end{array}$ & $\begin{array}{l}\stackrel{2}{N} \\
\stackrel{m}{0} \\
0 \\
\frac{U}{\Sigma}\end{array}$ & 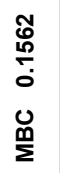 & $\begin{array}{l}\bar{\xi} \\
\text { छे } \\
\text { స }\end{array}$ & $\begin{array}{l}\bar{\xi} \\
\stackrel{\bar{\Xi}}{\mathrm{E}} \\
\stackrel{\circ}{\circ}\end{array}$ & $\begin{array}{l}\bar{\xi} \\
\text { 히 } \\
\text { ह }\end{array}$ & 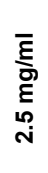 & 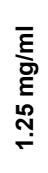 & 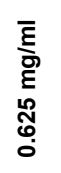 & 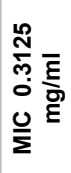 & 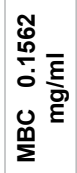 \\
\hline M. fortuitum & 6 & 5 & 4 & 3 & 1 & 1 & 0 & 0 & 7 & 5 & 4 & 3 & 3 & 1 & 0 & 0 & 5 & 3 & 2 & 1 & 1 & 0 & 0 & 0 \\
\hline $\begin{array}{c}M . \\
\text { sinegmatis }\end{array}$ & 5 & 4 & 2 & 2 & 1 & 1 & 0 & 0 & 8 & 5 & 3 & 0 & 0 & 0 & 0 & 0 & 7 & 5 & 5 & 3 & 2 & 0 & 0 & 0 \\
\hline $\begin{array}{c}M . \\
\text { abscessus }\end{array}$ & 7 & 6 & 4 & 3 & 2 & 2 & 0 & 0 & 8 & 6 & 4 & 3 & 2 & 1 & 0 & 0 & 5 & 3 & 2 & 1 & 0 & 0 & 0 & 0 \\
\hline M. phlei & 5 & 3 & 2 & 1 & 1 & 0 & 0 & 0 & 5 & 2 & 0 & 0 & 0 & 0 & 0 & 0 & 12 & 6 & 5 & 5 & 3 & 2 & 0 & 0 \\
\hline S. aureus & 5 & 3 & 2 & 2 & 1 & 0 & 0 & 0 & 10 & 7 & 5 & 4 & 4 & 3 & 0 & 0 & 6 & 6 & 4 & 2 & 1 & 0 & 0 & 0 \\
\hline $\begin{array}{c}K . \\
\text { pneumoniae }\end{array}$ & 1 & 0 & 0 & 0 & 0 & 0 & 0 & 0 & 9 & 6 & 5 & 3 & 3 & 2 & 0 & 0 & 8 & 6 & 3 & 2 & 1 & 1 & 0 & 0 \\
\hline E. coli & 5 & 4 & 3 & 2 & 2.0 & 1 & 0 & 0 & 7 & 5 & 3 & 2 & 2 & 2 & 0 & 0 & 9 & 7 & 4 & 3 & 2 & 1 & 0 & 0 \\
\hline $\begin{array}{c}P . \\
\text { aeruginosa }\end{array}$ & 7 & 5 & 3 & 3 & 3 & 2 & 0 & 0 & 10 & 7 & 6 & 5 & 3 & 1 & 0 & 0 & 9 & 8 & 5 & 3 & 3 & 1 & 0 & 0 \\
\hline S. typhi & 6 & 3 & 3 & 2 & 1 & 0 & 0 & 0 & 9 & 7 & 4 & 3 & 1 & 1 & 0 & 0 & 8 & 5 & 4 & 2 & 1 & 1 & 0 & 0 \\
\hline $\begin{array}{c}\text { S. } \\
\text { choleraesuis }\end{array}$ & 7 & 3 & 2 & 2 & 1 & 0 & 0 & 0 & 5 & 3 & 2 & 1 & 1 & 1 & 0 & 0 & 5 & 3 & 3 & 2 & 1 & 1 & 0 & 0 \\
\hline S. arizonae & 7 & 5 & 4 & 2 & 1 & 0 & 0 & 0 & 6 & 4 & 3 & 2 & 2 & 2 & 0 & 0 & 2 & 2 & 2 & 0 & 0 & 0 & 0 & 0 \\
\hline P. mirabilis & 2 & 0 & 0 & 0 & 0 & 0 & 0 & 0 & 8 & 5 & 4 & 3 & 2 & 2 & 0 & 0 & 5 & 2 & 2 & 1 & 0 & 0 & 0 & 0 \\
\hline $\begin{array}{c}A . \\
\text { hydrophilia }\end{array}$ & 4 & 4 & 3 & 2 & 2 & 1 & 0 & 0 & 5 & 3 & 2 & 1 & 1 & 1 & 0 & 0 & 7 & 5 & 2 & 2 & 1 & 0 & 0 & 0 \\
\hline B. subtilis & 11 & 7 & 5 & 4 & 4 & 3 & 0 & 0 & 7 & 5 & 3 & 2 & 1 & 1 & 0 & 0 & 2 & 0 & 0 & 0 & 0 & 0 & 0 & 0 \\
\hline S. typhi & 6 & 5 & 3 & 3 & 2 & 1 & 0 & 0 & 6 & 4 & 3 & 2 & 0 & 0 & 0 & 0 & 3 & 2 & 1 & 0 & 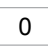 & 0 & 0 & 0 \\
\hline $\begin{array}{c}\text { S. } \\
\text { dysenteriae }\end{array}$ & 9 & 6 & 5 & 3 & 3 & 2 & 0 & 0 & 5 & 3 & 2 & 2 & 1 & 1 & 0 & 0 & 0 & 0 & 0 & 0 & 0 & 0 & 0 & 0 \\
\hline B. cepacia & 6 & 5 & 3 & 2 & 2 & 1 & 0 & 0 & 9 & 7 & 5 & 3 & 2 & 2 & 0 & 0 & 3 & 2 & 2 & 1 & 0 & 0 & 0 & 0 \\
\hline C. Koseri & 8 & 7 & 5 & 3 & 2 & 1 & 0 & 0 & 9 & 6 & 5 & 2 & 1 & 0 & 0 & 0 & 10 & 6 & 6 & 3 & 1 & 1 & 0 & 0 \\
\hline K. ozaenae & 5 & 3 & 2 & 2 & 1 & 1 & 0 & 0 & 5 & 3 & 1 & 1 & 0 & 0 & 0 & 0 & 7 & 4 & 3 & 2 & 1 & 0 & 0 & 0 \\
\hline
\end{tabular}

$P$ value $<0.0001 ; P$ value summary" $;$ Significantly different standard deviations? $(P<0.05)$ Yes

Table 1: Diameter of zones of inhibition of various fractions of ethyl acetate leaf extracts of Spondias mombin on the test bacteria.

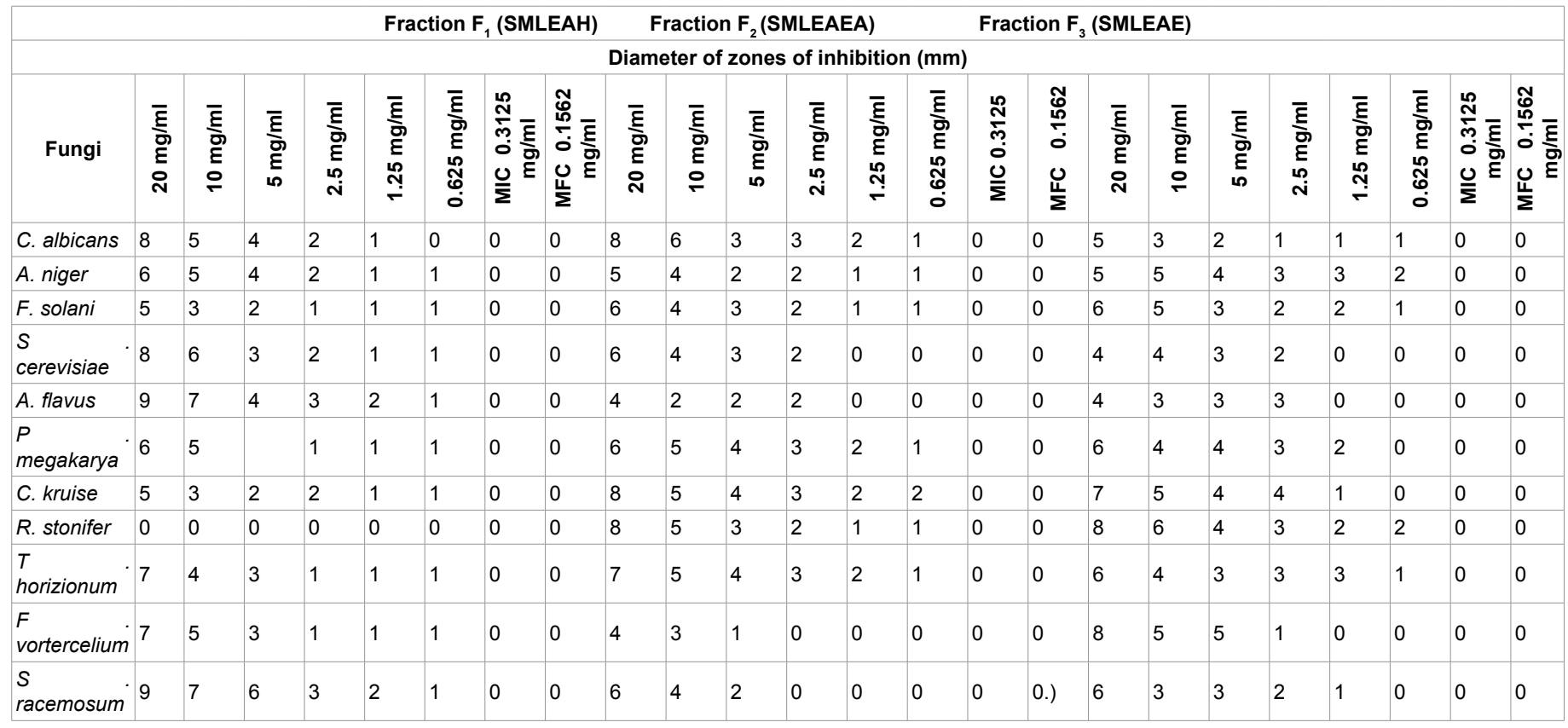

$P$ value $<0.0001 ; P$ value summary ${ }^{\prime \prime \prime} ;$ Significantly different standard deviations? $(P<0.05)$

Table 2: Diameter of zones of inhibition of partially purified ethyl acetate leaf extracts of Spondias mombin on the test fungi. 
Citation: Osuntokun OT, Idowu TO, Cristina GM (2018) Antibacterial and Antifungal Efficacy of Partially Partitioned Fractions of Spondias mombin (Linn) Extracts (Root, Leaf and Stem Bark) against Clinical and Environmental Isolates. Med Chem (Los Angeles) 8: 010-0017. doi: $10.4172 / 2161-0444.1000490$

(various fractions- $\mathrm{F}_{1}$ (SMLEAH), $\mathrm{F}_{2}$ (SMLEAEA) and $\mathrm{F}_{3}$ (SMLEAE) of ethyl acetate leaf extracts of $S$. mombin using $n$-hexane, ethyl acetate and ethanol as the eluting solvents. There was no significant inhibitory activity observed against the entire test bacteria at all the various concentrations of the extracts tested, except B. subtilis at 20 $\mathrm{mg} / \mathrm{ml}$ concentration where the highest zone of inhibition of $11.0 \mathrm{~mm}$ was recorded. Similarly, there was no significant antifungal activity observed in fractions $\mathrm{F}_{1}$ (SMLEAH), $\mathrm{F}_{2}$ (SMLEAEA) and $\mathrm{F}_{3}$ (SMLEAE) at concentrations of $2.5-0.625 \mathrm{mg} / \mathrm{ml}$.

\section{The antibacterial activity of partially purified ethyl acetate leaf extracts of Spondias mombin using ethyl acetate}

Tables 3 and 4 show the diameter of zones of inhibition of partially purified ethyl acetate leaf extracts of Spondias mombin using ethyl acetate as the eluting solvent. In Table 3, Fraction $\mathrm{F}_{1}$ (SMLEAH) showed significant inhibitory effect $(\mathrm{p} \leq 0.05)$ on all the test bacteria, except Klebsiella pneumoniae and Salmonella typhi at concentrations of 20.0-2.5 mg/ml. Meanwhile, fraction $\mathrm{F}_{2}$ (SMLEAEA) was not effective against Salmonella cholleraesuis, B. substilis, Citrobacter koseri and Salmonella typhi. Similarly, fraction $\mathrm{F}_{3}$ (SMLEAE) showed little or no inhibitory effect on most of the bacteria at all the concentration used (Table 3). Only fraction $\mathrm{F}_{1}$ (SMLEAH) showed significant antifungal effect $(\mathrm{p} \leq 0.05)$ on some of the test fungi (Table 4$)$.

\section{The antibacterial activity of partially purified ethanolic leaf extracts of Spondias mombin}

Tables 5 and 6 shows the various zones of growth inhibition of partially purified ethanolic leaf extracts of Spondias mombin fractions $\mathrm{F}_{1}$ (SMLEH), $\mathrm{F}_{2}$ (SMLEEA), $\mathrm{F}_{3}$ (SMLEE) on the test bacteria using $\mathrm{N}$ hexane, ethyl acetate and ethanol as the eluting solvents. The diameter of zones of inhibition varied with the test bacteria. Meanwhile, there was no significant $(\mathrm{p} \leq 0.05)$ antibacterial activity observed at concentrations of $1.25 \mathrm{mg} / \mathrm{ml}$ and $0.625 \mathrm{mg} / \mathrm{ml}$ of all the fractions. None of the shows no inhibitory activity against Proteus mirabilis at all the concentrations used, neither did fraction $F_{1}$ (SMLEH) show inhibitory effect on Burkholderia cepacia. Similarly, all the organisms were not susceptible to all the fractions except $\mathrm{F}_{1}$ which had diameter of zones of growth inhibition ranging from $4.0-1.0 \mathrm{~mm}$ at $5 \mathrm{mg} / \mathrm{ml}-0.625$ $\mathrm{mg} / \mathrm{ml}$ on Mycobacterium abscessus (Table 5). The antifungal activity of the partially purified ethanolic extracts of Spondias mombin fractions $\mathrm{F}_{1}$ (SMLEH), $\mathrm{F}_{2}$ (SMLEEA) and $\mathrm{F}_{3}$ (SMLEE) on the test fungi is presented in Table 6. Significant antifungal activity $(\mathrm{p} \leq 0.05)$ was observed at $20.0 \mathrm{mg} / \mathrm{ml}$ with most test fungi. Howerver, Trichoderma horizionum was not susceptible to all the three fractions, while Aspergillus niger and Syncephala strumracemosum were susceptible to only fraction $\mathrm{F}_{2}$ (SMLEEA).

\section{The antibacterial activity of partially purified ethanolic stem bark extracts of Spondias mombin using ethanol as the eluting solvent}

Tables 7 and 8 shows the diameter of zones of growth inhibition of the partially purified ethanolic stem bark extracts \{Fractions $F_{1}$ (SMSBEH), $\mathrm{F}_{2}$ (SMSBEEA), $\mathrm{F}_{3}$ (SMSBEE) $\}$ on the test as the eluting solvent. Significant inhibitory effect $(\mathrm{p} \leq 0.05)$ was observed in all the fractions at $20 \mathrm{mg} / \mathrm{ml}$ against most of the test bacteria. Meanwhile, zones of growth inhibition of the various fractions varied with the test bacteria with the highest diameter zone of $8.0 \mathrm{~mm}$ recorded in fraction $\mathrm{F}_{1}$ against Salmonella typhi. In Table 7 , fraction $\mathrm{F}_{1}(\mathrm{SMSBEH})$ showed a significant antifungal activity ( $\mathrm{p} \leq 0.05)$ on all the test fungi, except, Candida albicans, and Rhizopus stonifer that were not susceptible at all the various concentrations used. Similarly, fractions $\mathrm{F}_{2}$ (SMSBEEA) and $\mathrm{F}_{3}$ (SMSBEE) possessed significant inhibitory effect $(\mathrm{p} \leq 0.05)$ at 20.0-5.0 mglml on the test fungi, except, Candida kruise and Rhizopus stonifer (Table 8).

\section{Discussion}

The increasing trend of resistance to the antibiotics in current use has drawn the attention of researchers to natural alternative treatments of bacterial infections as potential sources of new, novel antimicrobial agents. This study indicated that Spondias mombin could be used as medicinal plants in various regions of the world are active against a broad spectrum of clinical and environmental Isolates In this study, all the plant parts (leaf, root, and stem bark) assayed possessed varying degree of antimicrobial activities. The partially purified extracts possessed antimicrobial activity with pronounced activity recorded in the stem bark of the plant extract of Spondias mombin. Ndukwe [9] and other researchers reported that partially purified fractions of Spondias mombin have impressive antimicrobial effect on E. coli and S. typhi [1012].

The result obtained from flux fractionating of extract revealed that the fractions of stem bark and leaf of Spondias mombin using ethyl acetate as the eluting solvent showed better antimicrobial activity compared to $n$-hexane and ethanol which has been earlier reported. Ethyl acetate fractions of Spondias mombin extract were more potent in activity against the entire test organisms than other solvent fractions. The difference in polarity among the various solvents are perhaps responsible for the differences in solubility of plant active compounds, hence variation in degree of activity [13].

Other active eluting solvents in the study include ethanol and $n$-hexane [14]. Gram negative bacteria are reported to be resistant against most antibacterial agents as a result of the more complicated nature of their cell wall compared to Gram positive bacteria $[9,15,16]$. However, Spondias mombin was found to be active against the two groups of Clinical and Environmental Isolates underlining their ethnomedicinal use for treatment of various infectious diseases [1720].

Moreover, the ethyl acetate extract was highly effective against Gram positive and negative bacteria (clinical and environmental Isolates) as well as all fungal species while the ethyl acetate extract only had high antimicrobial activities against all test bacteria species but not against fungal species except on C. kruise, F. vortercelium and $S$. racemosum. This finding established active principles of most species of Spondias mombin. Aliyu et al. [20] found the ethyl acetate and n-butanol extracts as the most active extracts of Spondias mombin while Das et al. [19] established the antimicrobial activity of ethyl acetate extract of Spondias mombin (Linn).

Overall the test organisms were most sensitive to the ethyl acetate extract followed by the ethanol extract. The other extracts $n$-hexane only exhibited limited activities, This result shows that ethyl acetate are the most efficient extracting solvents for active principles of these plants. The ethyl acetate extract also contain novel bioactive compounds which might be present in low concentrations but which on further purification might demonstrate equally high antimicrobial activities Osuntokun et al. [21].

In conclusion, the broad spectrum activity exhibited by Spondias mombin extracts establishes the scientific basis for their use as ethno medicine and their potential for use for development of novel antibacterial and antifungal agents effective for treatment of microbial 
Citation: Osuntokun OT, Idowu TO, Cristina GM (2018) Antibacterial and Antifungal Efficacy of Partially Partitioned Fractions of Spondias mombin (Linn) Extracts (Root, Leaf and Stem Bark) against Clinical and Environmental Isolates. Med Chem (Los Angeles) 8: 010-0017. doi: $10.4172 / 2161-0444.1000490$

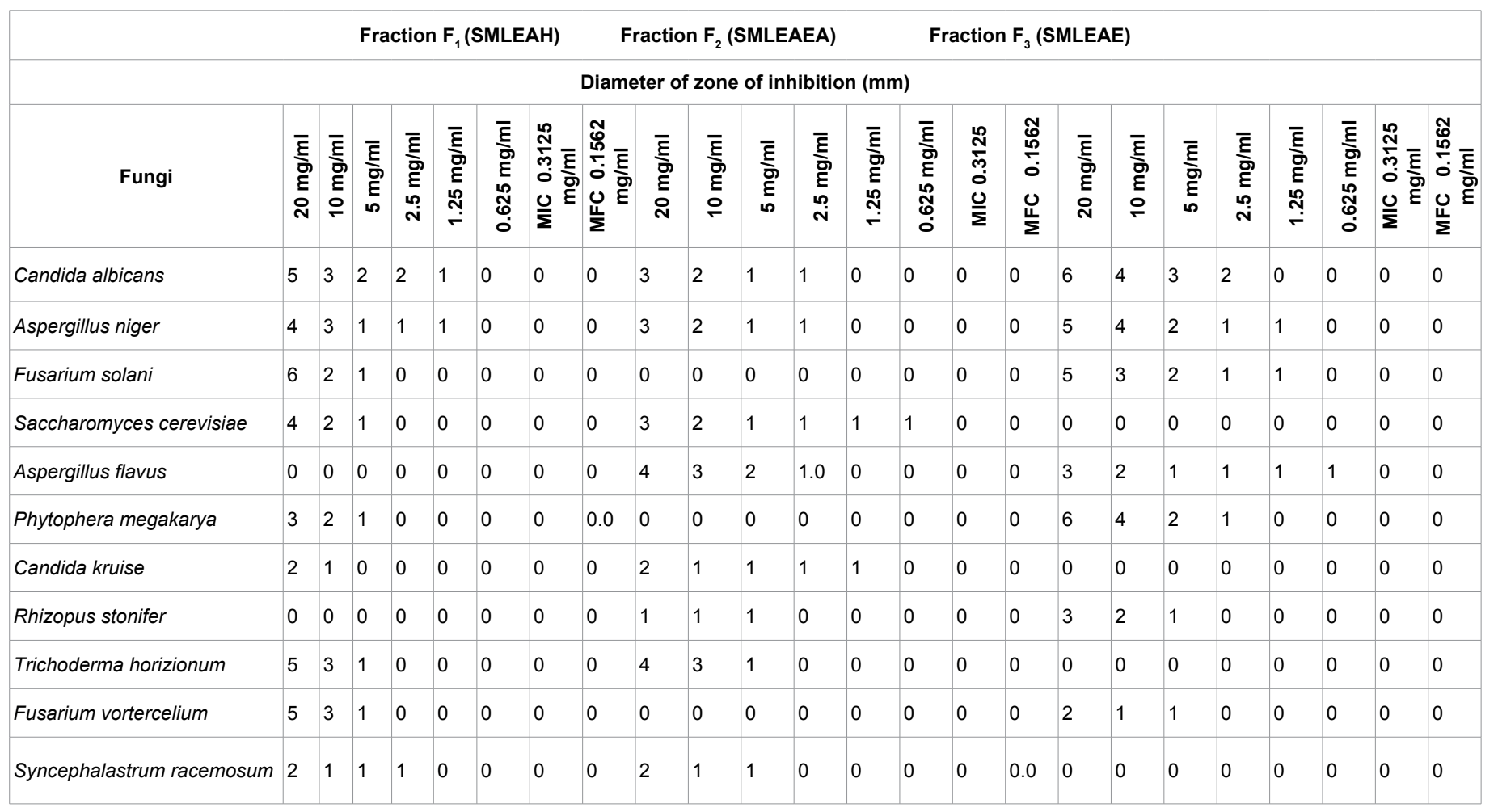

$P$ value $<0.0001 ; P$ value summary ${ }^{*+* *}$; Significantly different standard deviations? $(P<0.05)$

Table 3: Diameter of zone of inhibition of partially purified ethyl acetate leaf extracts of Spondias mombin on the test fungi using ethyl acetate as the eluting solvent.

\begin{tabular}{|c|c|c|c|c|c|c|c|c|c|c|c|c|c|c|c|c|c|c|c|c|c|c|c|c|}
\hline \multicolumn{9}{|c|}{ Fraction $\mathrm{F}_{1}(\mathrm{SMLEH})$} & \multicolumn{7}{|c|}{ Fraction $F_{2}$ (SMLEEA) } & \multicolumn{9}{|c|}{ Fraction $\mathrm{F}_{3}(\mathrm{SMLEE})$} \\
\hline \multicolumn{25}{|c|}{ Diameter of zones of inhibition $(\mathrm{mm})$} \\
\hline Bacteria & $\begin{array}{l}\bar{\xi} \\
\text { Бे } \\
\text { స }\end{array}$ & 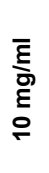 & 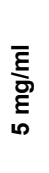 & 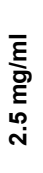 & 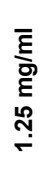 & 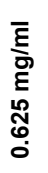 & 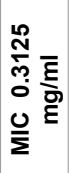 & 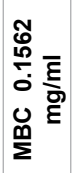 & $\begin{array}{l}\bar{\xi} \\
\text { है } \\
\text { શે }\end{array}$ & $\begin{array}{l}\bar{\xi} \\
\stackrel{0}{\Xi} \\
\stackrel{0}{\circ}\end{array}$ & $\begin{array}{l}\bar{\xi} \\
\stackrel{\bar{g}}{\xi} \\
{ }^{2}\end{array}$ & $\begin{array}{l}\bar{\xi} \\
\stackrel{\Xi}{\Xi} \\
\stackrel{n}{N}\end{array}$ & 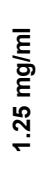 & 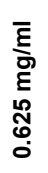 & 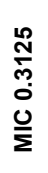 & 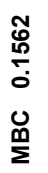 & $\begin{array}{l}\bar{\xi} \\
\text { ڤ్ } \\
\text { స }\end{array}$ & $\begin{array}{l}\bar{\xi} \\
\text { g } \\
\stackrel{\Xi}{\circ}\end{array}$ & 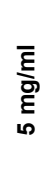 & $\begin{array}{l}\bar{\xi} \\
\text { ఫ్ } \\
\underline{n} \\
\text { Ni }\end{array}$ & 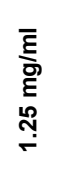 & $\begin{array}{l}\bar{\xi} \\
\text { छ } \\
\stackrel{్}{0} \\
0 \\
0\end{array}$ & 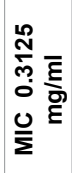 & 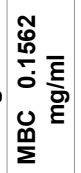 \\
\hline M. fortuitum & 5 & 3 & 2 & 1 & 0 & 0 & 0 & 0 & 6 & 4 & 3 & 3 & 1 & 0 & 0 & 0 & 5 & 4 & 3 & 3 & 1 & 0 & 0 & 0 \\
\hline M. sinegmatis & 7 & 5 & 3 & 1 & 1 & 0 & 0 & 0 & 4 & 3 & 3 & 3 & 2 & 1 & 0 & 0 & 7 & 5 & 3 & 2 & 1 & 0 & 0 & 0 \\
\hline M. abscessus & 0 & 0 & 4 & 2 & 1 & 1 & 0 & 0 & 0 & 0 & 0 & 0 & 0 & 0 & 0 & 0 & 1 & 0 & 0 & 0 & 0 & 0 & 0 & 0 \\
\hline M. phlei & 7 & 5 & 3 & 2 & 1 & 1 & 0 & 0 & 5 & 2 & 2 & 1 & 1 & 0 & 0 & 0 & 6 & 4 & 1 & 1 & 0 & 0 & 0 & 0 \\
\hline S. aureus & 5 & 3 & 2 & 2 & 1 & 1 & 0 & 0 & 8.0 & 5 & 3 & 2 & 1 & 1 & 0 & 0 & 5 & 3 & 3 & 2 & 1 & 1 & 0 & 0 \\
\hline K. pneumoniae & 4 & 2 & 2 & 2 & 0 & 0 & 0 & 0 & 8.0 & 5 & 4 & 3 & 2 & 2 & 0 & 0 & 7 & 5 & 2.0 & 2 & 1 & 0 & 0 & 0 \\
\hline E. coli & 6 & 4 & 3 & 2 & 1 & 1 & 0 & 0 & 7 & 5 & 4 & 3 & 2 & 1 & 0 & 0 & 2 & 2 & 2 & 0 & 0 & 0 & 0 & 0 \\
\hline P. aeruginosa & 7 & 5 & 3 & 3 & 0 & 0 & 0 & 0 & 6 & 5 & 3 & 2 & 1 & 0 & 0 & 0 & 9 & 8 & 7 & 4 & 2 & 1 & 0 & 0 \\
\hline S. typhi & 4 & 2 & 2 & 1 & 0 & 0 & 0 & 0 & 4 & 3 & 2 & 2 & 1 & 1 & 0 & 0 & 6 & 3 & 3 & 2 & 1 & 0 & 0 & 0 \\
\hline S. choleraesuis & 4 & 3 & 1 & 0 & 0 & 0 & 0 & 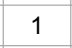 & 5 & 4 & 3 & 3 & 1 & 0 & 0 & 0 & 5 & 4 & 3 & 3 & 0 & 0 & 0 & 0 \\
\hline $\begin{array}{c}S . \\
\text { arizonae }\end{array}$ & 6 & 4 & 2 & 1 & 1 & 1 & 0 & 0 & 3 & 3 & 3 & 3 & 1 & 1 & 0 & 0 & 4 & 3 & 3 & 2 & 2 & 1 & 0 & 0 \\
\hline P. mirabilis & 0 & 0 & 0 & 0 & 0 & 0 & 0 & 0 & 0 & 0 & 0 & 0 & 0 & 0 & 0 & 0 & 0 & 0 & 0 & 0 & 0 & 0 & 0 & 0 \\
\hline A. hydrophilia & 3 & 2 & 1 & 0 & 0 & 0 & 0 & 0 & 3 & 2 & 2 & 1 & 1 & 0 & 0 & 0 & 5 & 3 & 2 & 1 & 1 & 0 & 0 & 0 \\
\hline B. subtilis & 4 & 3 & 1 & 0 & 0 & 0 & 0 & 0 & 6 & 4 & 4 & 3 & 1 & 1 & 0 & 0 & 7 & 5 & 4 & 3 & 1 & 1 & 0 & 0 \\
\hline S. typhi & 5 & 3 & 1 & 0 & 0 & 0 & 0 & 0 & 6 & 5 & 4 & 3.0 & 2 & 2 & 0 & 0 & 6 & 5 & 4 & 3 & 2 & 1 & 0 & 0 \\
\hline S. dysenteriae & 3 & 2 & 1 & 0 & 0 & 0 & 0 & 0 & 5 & 3 & 3 & 2 & 1 & 1 & 0 & 0 & 8 & 5 & 3 & 2 & 1 & 0 & 0 & 0 \\
\hline B. cepacia & 0 & 0 & 0 & 0 & 0 & 0 & 0 & 0 & 9 & 5 & 4 & 3 & 2 & 1 & 0 & 0 & 6 & 5 & 4 & 3 & 2 & 1 & 0 & 0 \\
\hline C. koseri & 4 & 3 & 2 & 1 & 0 & 0 & 0 & 0 & 5 & 3 & 3 & 3 & 1 & 0 & 0 & 0 & 6 & 5 & 3 & 2 & 1 & 1 & 0 & 0 \\
\hline K. ozaenae & 2 & 4 & 3 & 2 & 4 & 3 & 0 & 0 & 4 & 3 & 2 & 4 & 3 & 2 & 4 & 3 & 4 & 3 & 2 & 2 & 1 & 0 & 0 & 0 \\
\hline
\end{tabular}

$P$ value $<0.0001 ; P$ value summary" Significantly different standard deviations? $(P<0.0)$

Table 4: Diameter of zones of inhibition of partially purified ethanolic leaf extracts of Spondias mombin on the test bacteria. 
Citation: Osuntokun OT, Idowu TO, Cristina GM (2018) Antibacterial and Antifungal Efficacy of Partially Partitioned Fractions of Spondias mombin (Linn) Extracts (Root, Leaf and Stem Bark) against Clinical and Environmental Isolates. Med Chem (Los Angeles) 8: 010-0017. doi: $10.4172 / 2161-0444.1000490$

\begin{tabular}{|c|c|c|c|c|c|c|c|c|c|c|c|c|c|c|c|c|c|c|c|c|c|c|c|c|}
\hline \multicolumn{10}{|c|}{ Fraction $F_{1}($ SMLEH) } & \multicolumn{5}{|c|}{ Fraction $\mathrm{F}_{2}$ (SMLEEA) } & \multicolumn{10}{|c|}{ Fraction $\mathrm{F}_{3}$ (SMLEE) } \\
\hline \multicolumn{25}{|c|}{ Diameter of zones of inhibition } \\
\hline Fungi & 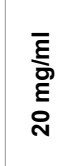 & 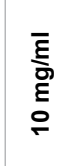 & $\begin{array}{l}\bar{\xi} \\
\underset{\text { छे }}{E}\end{array}$ & 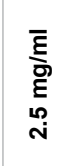 & 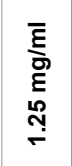 & 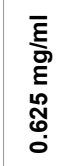 & 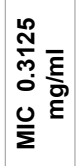 & 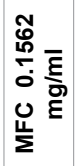 & $\begin{array}{l}\bar{\xi} \\
\bar{\Xi} \\
\stackrel{N}{ }\end{array}$ & $\begin{array}{l}\bar{\xi} \\
\bar{\emptyset} \\
\xi \\
\end{array}$ & $\begin{array}{l}\bar{\xi} \\
\stackrel{\bar{g}}{\xi} \\
\text { م }\end{array}$ & $\begin{array}{l}\bar{E} \\
\text { Oे } \\
E \\
\stackrel{n}{N}\end{array}$ & 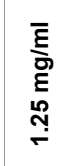 & 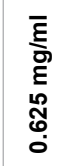 & $\begin{array}{l}\stackrel{N}{N} \\
\stackrel{0}{0} \\
\frac{0}{\Sigma}\end{array}$ & 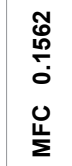 & 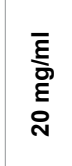 & $\begin{array}{l}\bar{\xi} \\
\stackrel{\Xi}{\Xi} \\
\stackrel{-}{-}\end{array}$ & $\begin{array}{l}\bar{\xi} \\
\stackrel{\bar{g}}{\xi} \\
\text { ') }\end{array}$ & $\begin{array}{l}\bar{\xi} \\
\stackrel{్}{\xi} \\
\underline{\omega} \\
\text { N }\end{array}$ & $\begin{array}{l}\overline{\bar{\varepsilon}} \\
\stackrel{5}{\xi} \\
\stackrel{\leftrightarrow}{\stackrel{n}{q}}\end{array}$ & 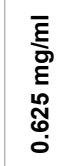 & 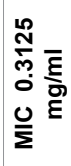 & 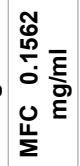 \\
\hline C. albicans & 6 & 4 & 3 & 2 & 0 & 0 & 0 & 0 & 6 & 5 & 3 & 3 & 1 & 0 & 0 & 0 & 5 & 2 & 2 & 1 & 0 & 0 & 0 & 0 \\
\hline A. niger & 0 & 0 & 0 & 0 & 0 & 0 & 0 & 0 & 5 & 3 & 2 & 1 & 1 & 0 & 0 & 0 & 0 & 0 & 0 & 0 & 0 & 0 & 0 & 0 \\
\hline F. solani & 0 & 0 & 0 & 0 & 0 & 0 & 0 & 0 & 6 & 4 & 3 & 1 & 0 & 0 & 1 & 0 & 3 & 2 & 1 & 1 & 0 & 0 & 0 & 0 \\
\hline $\begin{array}{l}\text { S } \\
\text { cerevisiae }\end{array}$ & 5 & 3 & 2 & 1 & 1 & 1 & 0 & 0 & 3 & 2 & 2 & 1 & 0 & 0 & 0 & 0 & 7 & 5 & 2 & 2 & 1 & 1 & 0 & 0 \\
\hline A. flavus & 3 & 2 & 1 & 1 & 0 & 0 & 0 & 0 & 4 & 3 & 2 & 1 & 1 & 0 & 0 & 0 & 0 & 0 & 0 & 0 & 0 & 0 & 0 & 0 \\
\hline $\begin{array}{l}P \\
\text { megakarya }\end{array}$ & 4 & 3 & 2 & 2 & 1 & 1 & 0 & 0 & 0 & 0 & 0 & 0 & 0 & 0 & 0 & 0 & 0 & 2 & 2 & 1 & 0 & 0 & 0 & 0 \\
\hline C. kruise & 5 & 4 & 2 & 1 & 1 & 0 & 0 & 0 & 6 & 3 & 2 & 0 & 0 & 0 & 0 & 0 & 5 & 4 & 4 & 3 & 2 & 1 & 0 & 0 \\
\hline R. stonifer & 7 & 4 & 3 & 2 & 1 & 0 & 0 & 0 & 2 & 1 & 1 & 1 & 1 & 1 & 0 & 0 & 3 & 2 & 1 & 0 & 0 & 0 & 0 & 2 \\
\hline $\begin{array}{l}T \\
\text { horizionum }\end{array}$. & 0 & 0 & 0 & 0 & 0 & 0 & 0 & 0 & 0 & 0 & 0 & 0 & 0 & 0 & 0 & 0 & 0 & 0 & 0 & 0 & 0 & 0 & 0 & 0 \\
\hline $\begin{array}{l}\text { vortercelium } \\
\text { volu }\end{array}$ & 4 & 2 & 2 & 1 & 1 & 0 & 0 & 0 & 5 & 4 & 3 & 2 & 1 & 0 & 0 & 0 & 6 & 3 & 3 & 2 & 1 & 0 & 0 & 2 \\
\hline $\begin{array}{l}\text { S } \\
\text { racemosum }\end{array}$ & 0 & 0 & 0 & 0 & 0 & 0 & 0 & 0 & 4 & 3 & 1 & 1 & 1 & 1 & 0 & 0 & 0 & 0 & 0 & 0 & 0 & 0 & 0 & 0 \\
\hline
\end{tabular}

$P$ value $<0.0001 ; P$ value summary ${ }^{\prime \prime \prime} ;$ Significantly different standard deviations? $(P<0.05)$

Table 5: Diameter of zones of inhibition of partially purified ethanolic leaf extracts of Spondias mombin on the test fungi.

\begin{tabular}{|c|c|c|c|c|c|c|c|c|c|c|c|c|c|c|c|c|c|c|c|c|c|c|c|c|}
\hline \multicolumn{10}{|c|}{ Fraction $\mathrm{F}_{1}$ (SMSBEH) } & racti & $n F_{2}($ & MSB & EEA) & \multicolumn{11}{|c|}{ Fraction $\mathrm{F}_{3}$ (SMSBEE) } \\
\hline \multicolumn{25}{|c|}{ Diameter of zones of inhibition } \\
\hline Bacteria & $\begin{array}{l}\bar{\xi} \\
\text { ڤ్ } \\
\text { సે }\end{array}$ & $\begin{array}{l}\bar{\xi} \\
\text { ㅁ } \\
\underline{ } \\
\end{array}$ & $\begin{array}{l}\bar{\xi} \\
\text { छे } \\
\text { हn }\end{array}$ & $\begin{array}{l}\bar{\xi} \\
\stackrel{5}{\xi} \\
\stackrel{\sim}{N}\end{array}$ & $\begin{array}{l}\bar{\xi} \\
\bar{g} \\
\stackrel{5}{\mid} \\
\stackrel{n}{-}\end{array}$ & 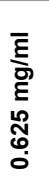 & 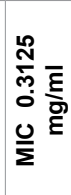 & 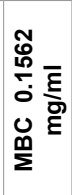 & 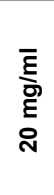 & $\begin{array}{l}\bar{\xi} \\
\stackrel{ }{\bar{E}} \\
\stackrel{0}{\circ}\end{array}$ & $\begin{array}{l}\bar{\xi} \\
\stackrel{\bar{g}}{\xi} \\
\stackrel{5}{n}\end{array}$ & $\begin{array}{l}\bar{\xi} \\
\stackrel{5}{E} \\
\stackrel{n}{N}\end{array}$ & 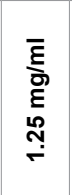 & 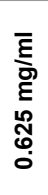 & $\begin{array}{l}\stackrel{n}{N} \\
\stackrel{m}{0} \\
\stackrel{0}{0} \\
\frac{0}{\Sigma}\end{array}$ & 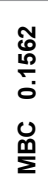 & $\begin{array}{l}\bar{\xi} \\
\text { छे } \\
\text { సิ }\end{array}$ & $\begin{array}{l}\bar{\xi} \\
\bar{\Xi} \\
\stackrel{ }{\circ}\end{array}$ & $\begin{array}{l}\bar{\xi} \\
\text { 하 } \\
\stackrel{\xi}{\circ}\end{array}$ & $\begin{array}{l}\bar{\xi} \\
\stackrel{5}{E} \\
\stackrel{n}{N}\end{array}$ & 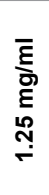 & 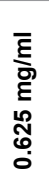 & $\begin{array}{l}\stackrel{D}{E} \\
\stackrel{N}{N} \\
\stackrel{N}{m} \\
0 \\
0 \\
\frac{U}{\Sigma}\end{array}$ & 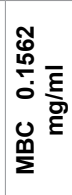 \\
\hline M. fortuitum & 4 & 3 & 3 & 2.0 & 2 & 0 & 0 & 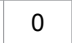 & 2 & 1 & 1 & 0 & 0 & 0 & 0 & 0 & 4 & 3 & 2 & 1 & 0 & 0 & 0 & 0 \\
\hline M. sinegmatis & 4 & 2 & 2 & 2 & 2 & 0 & 0 & 0 & 0 & 0 & 0 & 0 & 0 & 0 & 0 & 0 & 3 & 2 & 1 & 0 & 0 & 0 & 0 & 0 \\
\hline M. abscessus & 3 & 3 & 2 & 1 & 1 & 0 & 0 & 0 & 1 & 0 & 0 & 0 & 0 & 0 & 0 & 0 & 4 & 3 & 2 & 1 & 0 & 0 & 0 & 0 \\
\hline M. phlei & 3 & 2 & 1 & 0 & 0 & 0 & 0 & 0 & 1 & 1 & 0 & 0 & 0 & 0 & 0 & 0 & 4 & 2 & 2 & 0 & 0 & 0 & 0 & 0 \\
\hline S. aureus & 2 & 1 & 0 & 0 & 0 & 0 & 0 & 0 & 7 & 5 & 4 & 3 & 3 & 2 & 0 & 0 & 6 & 4 & 4 & 3 & 2 & 1 & 0 & 0 \\
\hline K pneumoniae & 4 & 3 & 2 & 1 & 0 & 0 & 0 & 0 & 5 & 3 & 3 & 3 & 3 & 0 & 0 & 0 & 6 & 4 & 3 & 3 & 3 & 1 & 0 & 0 \\
\hline E. coli & 5 & 3 & 1 & 0 & 0 & 0 & 0 & 0 & 8 & 5 & 3 & 3 & 2. 0 & 1 & 0 & 0 & 7 & 5 & 4 & 4 & 1 & 0 & 0 & 0 \\
\hline$P$. aeruginosa & 8 & 6 & 6 & 3 & 0 & 0 & 0 & 0 & 7 & 5 & 3 & 3 & 2 & 1 & 0 & 0 & 1 & 1 & 1 & 1 & 0 & 0 & 0 & 0 \\
\hline S. typhi & 6 & 4 & 2 & 1 & 1 & 0 & 0 & 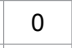 & 5 & 3 & 2 & 1 & 1 & 0 & 0 & 0 & 5 & 3 & 2 & 1 & 1 & 0 & 0 & 0 \\
\hline S. choleraesuis & 5 & 4 & 4 & 3 & 1 & 0 & 0 & 0 & 4 & 3 & 2 & 1 & 1 & 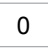 & 0 & 0 & 0 & 0 & 0 & 0 & 0 & 0 & 0 & 0 \\
\hline$S$. & & & & & & & & & & & & & & & & & & & & & & & & \\
\hline arizonae & 5 & 3 & 2 & 2 & 1 & 1 & 0 & 0 & 9 & 7 & 5 & 3 & 2 & 1 & 0 & 0 & 5 & 4 & 2 & 2 & 1 & 1 & 0 & 0 \\
\hline P. mirabilis & 6 & 5 & 4 & 3 & 2 & 2 & 0 & 0 & 6 & 5 & 3 & 2 & 1 & 0 & 0 & 0 & 6 & 5 & 4 & 3 & 2 & 2 & 0 & 0 \\
\hline A. hydrophilia & 4 & 3 & 2 & 1 & 1 & 0 & 0 & 0 & 7 & 5 & 4 & 2 & 1 & 0 & 0 & 0 & 0 & 0 & 0 & 0 & 0 & 0 & 0 & 0 \\
\hline B/subtilis & 5 & 2 & 2 & 1 & 0 & 0 & 0 & 0 & 8 & 5 & 4 & 3 & 1 & 1 & 0 & 0 & 5 & 3 & 2 & 2 & 1 & 0 & 0 & 0 \\
\hline S. typhi & 7 & 4 & 4 & 2 & 1 & 0 & 0 & 0 & 6 & 3 & 2 & 1 & 0 & 0 & 0 & 0 & 0 & 0 & 0 & 0 & 0 & 0 & 0 & 0 \\
\hline S. dysenteriae & 2 & 1 & 0 & 0 & 0 & 0 & 0 & 0 & 2 & 2 & 1 & 1 & 1 & 1 & 0 & 0 & 1 & 0 & 0 & 0 & 0 & 0 & 0 & 0 \\
\hline B. cepacia & 4 & 5 & 3 & 2 & 2 & 1 & 0 & 0 & 0 & 0 & 0 & 0 & 0 & 0 & 0 & 0 & 0 & 0 & 0 & 0 & 0 & 0 & 0 & 0 \\
\hline C. koseri & 8 & 6 & 3 & 3 & 2 & 1 & 0 & 0 & 7 & 6 & 5 & 3 & 1 & 0 & 0 & 0 & 7 & 5 & 3 & 3 & 2 & 2 & 0 & 0 \\
\hline K. ozaenae & 5 & 4 & 3 & 2 & 1 & 0 & 0 & 0 & 4 & 3 & 1 & 1 & 0 & 0 & 0 & 0 & 0 & 0 & 0 & 0 & 0 & 0 & 0 & 0 \\
\hline
\end{tabular}

$P$ value $<0.0001 ; P$ value summary Significantly different standard deviations? $(P<0.05)$

Table 6: Diameter of zones of inhibition of partially purified ethanolic leaf extracts of Spondias mombin on the test bacteria. 
Citation: Osuntokun OT, Idowu TO, Cristina GM (2018) Antibacterial and Antifungal Efficacy of Partially Partitioned Fractions of Spondias mombin (Linn) Extracts (Root, Leaf and Stem Bark) against Clinical and Environmental Isolates. Med Chem (Los Angeles) 8: 010-0017. doi: $10.4172 / 2161-0444.1000490$

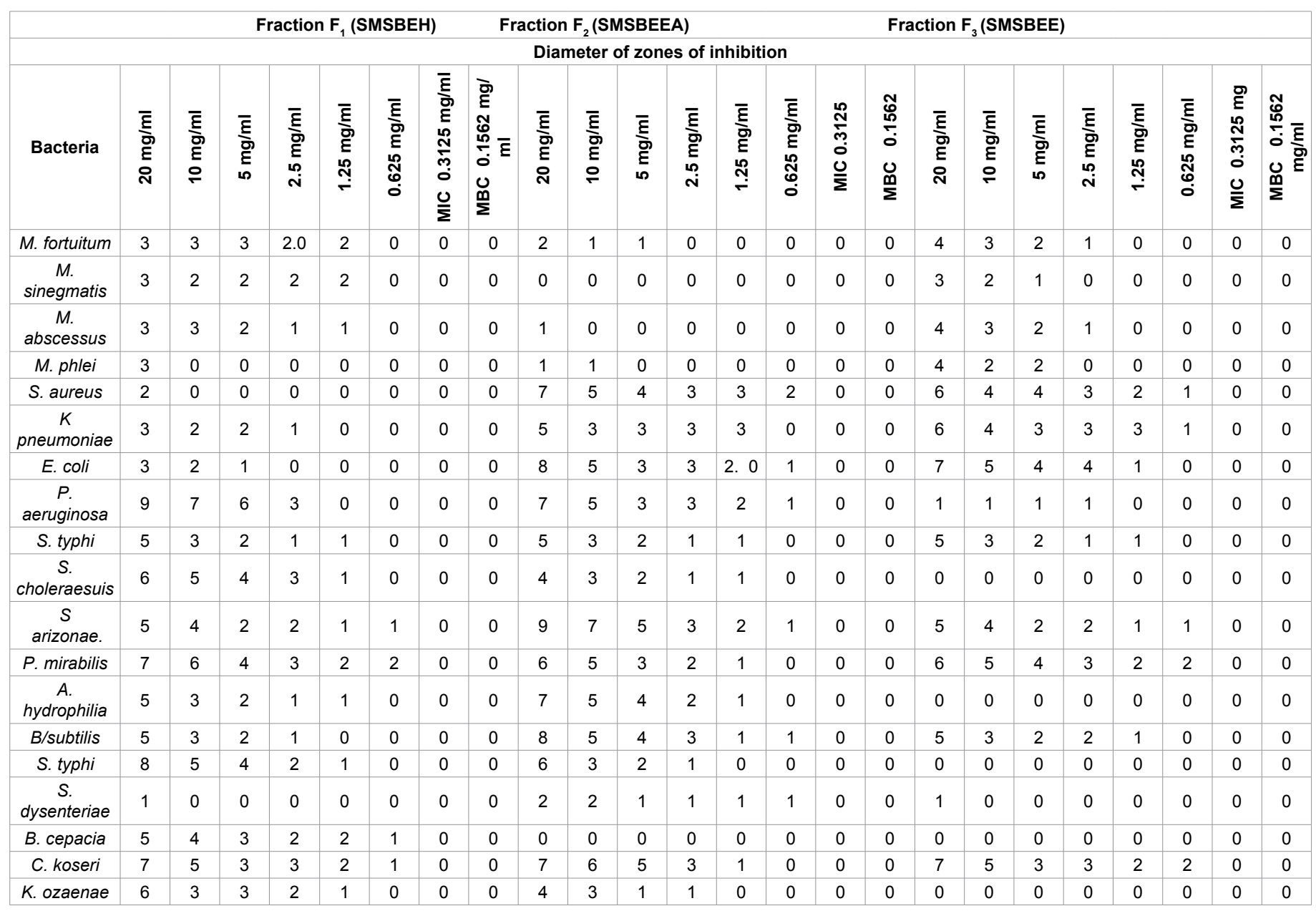

$P$ value $<0.0001 ; P$ value summary" Significantly different standard deviations? $(P<0.05)$

Table 7: Diameter of zones of inhibition of partially purified ethanolic stem bark extracts of Spondias mombin on the test bacteria.

\begin{tabular}{|c|c|c|c|c|c|c|c|c|c|c|c|c|c|c|c|c|c|c|c|c|c|c|c|c|c|}
\hline \multicolumn{10}{|c|}{ Fraction $F_{1}(S M S B E H)$} & & & & & & & & & & & & & & & & \\
\hline \multicolumn{26}{|c|}{ Diameter of zones of inhibition } \\
\hline Fungi & 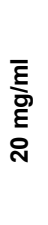 & $\begin{array}{l}\bar{\xi} \\
\text { 을 } \\
\underline{ }\end{array}$ & $\begin{array}{l}\overline{\underline{\xi}} \\
\stackrel{\mathrm{g}}{\mathrm{E}} \\
\mathrm{n}\end{array}$ & 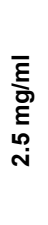 & 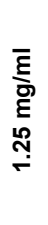 & 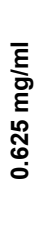 & 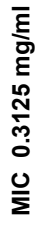 & 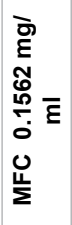 & $\begin{array}{l}\bar{\xi} \\
\text { 을 } \\
\text { ํ. }\end{array}$ & $\begin{array}{l}\bar{\xi} \\
\text { 휠 } \\
\text { 응 }\end{array}$ & $\begin{array}{l}\bar{\xi} \\
\stackrel{\bar{\Xi}}{E}\end{array}$ & 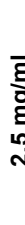 & 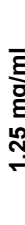 & & & & 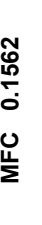 & $\begin{array}{l}\bar{\xi} \\
\text { ఏ్ } \\
\text { Е } \\
\text { నิ }\end{array}$ & 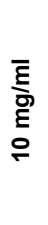 & 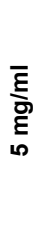 & 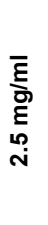 & 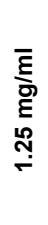 & 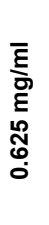 & 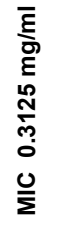 & 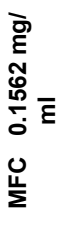 \\
\hline C. albicans & 0 & 0 & 0 & 0 & 0 & 0 & 0 & 0 & 4 & 4 & 3.0 & 1 & 0 & & & & 0 & 8 & 6 & 4 & 3 & 2.0 & 2 & 0 & 0 \\
\hline A. niger & 6 & 4 & 4 & 3 & 1 & 1 & 0 & 0 & 0 & 0 & 0 & 0 & 0 & & & & 0 & 5 & 3 & 2.0 & 1 & 0 & 0 & 0 & 0 \\
\hline F. solani & 5 & 4 & 3 & 2 & 1 & 1 & 0 & 0 & 5 & 4 & 2 & 0 & 0 & & & & 0 & 8 & 5 & 3 & 2 & 1 & 1 & 0 & 0 \\
\hline S. cerevisiae & 7 & 5 & 4 & 3 & 2 & 1 & 0 & 0 & 7 & 6 & 4 & 3 & 1 & & & & 0 & 2 & 1 & 1 & 1 & & 0 & 0 & 0 \\
\hline A. flavu & 5 & 3 & 2 & 1 & 0 & 0 & 0 & 0 & 0 & 0 & 0 & 0 & 0 & & & & 0 & 4 & 2 & 1 & 1 & 0 & 0 & 0 & 0 \\
\hline$P$ megakarya & 5 & 4 & 3 & 2 & 1 & 1 & 0 & 0 & 5 & 3 & 2 & 2 & 1 & & & & 0 & 7 & 5 & 3 & 1 & 1 & 0 & 0 & 0 \\
\hline C. kruise & 7 & 5 & 4 & 2 & 1 & 1 & 0 & 0 & 0 & 0 & 0 & 0 & 0 & & & & 0 & 0 & 0 & 0 & 0 & 0 & 0 & 0 & 0 \\
\hline R. stonifer & 1 & 0 & 0 & 0 & 0 & 0 & 0 & 0 & 1 & 0 & 0 & 0 & 0 & & & & 0 & 3 & 2 & 1 & 1 & 0 & 0 & 0 & 0.0 \\
\hline $\begin{array}{c}T . \\
\text { horizionum }\end{array}$ & 5 & 4 & 3 & 2 & 1 & 1 & 0 & 0 & 5 & 4 & 3 & 2 & 2 & & & & 0 & 0 & 0 & 0 & 0 & 0 & 0 & 0 & 0 \\
\hline $\begin{array}{c}F . \\
\text { vortercelium }\end{array}$ & 7 & 5 & 3 & 3 & 2 & 1 & 0 & 0 & 5 & 4 & 3 & 3 & 3 & 2 & & & 0 & 4 & 2 & 1 & 0 & 0 & 0 & 0 & 0 \\
\hline $\begin{array}{c}\mathrm{S} . \\
\text { racemosum }\end{array}$ & 5 & 3 & 3 & 2 & 1 & 0 & 0 & 0 & 5 & 3 & 3 & 2 & 1 & & & & 0 & 3 & 2 & 1 & 0 & 0 & 0 & 0 & 0 \\
\hline
\end{tabular}

$P$ value $<0.0001 ; P$ value summary ${ }^{* * * *}$ Significantly different standard deviations? $(P<0.05)$

Table 8: Diameter of zones of inhibition of partially purified ethanolic stem bark extracts of Spondias mombin on the test fungi. 
Citation: Osuntokun OT, Idowu TO, Cristina GM (2018) Antibacterial and Antifungal Efficacy of Partially Partitioned Fractions of Spondias mombin (Linn) Extracts (Root, Leaf and Stem Bark) against Clinical and Environmental Isolates. Med Chem (Los Angeles) 8: 010-0017. doi: $10.4172 / 2161-0444.1000490$

infectious diseases. Their usefulness in the formulation of antibiotics is also recommended if the active principles can be isolated and purified. Further investigations of the Spondias mombin plants for the isolation, purification and characterization of the active principles are ongoing.

\section{Recommendations}

It is thereby recommended to explore and total purification of medicinal plants such as the one studied, Spondias mombin, to fight against public health problems.

\section{Nomenclature}

\section{Code \\ Fractions of Different Extracts}

\begin{tabular}{|c|c|}
\hline SMREH & $\begin{array}{c}N \text {-hexane fraction of the ethanol extract of the S. mombin } \\
\text { root }\end{array}$ \\
\hline SMREEA & Ethyl acetate fraction of the ethanol extract of the $S$. \\
\hline SMREE & Ethanol fraction of the ethan \\
\hline MREAH & $\begin{array}{r}N \text {-hexane fraction of the et } \\
\text { momb }\end{array}$ \\
\hline MREAEA & $\begin{array}{r}\text { Ethyl acetate fraction of } \mathrm{t} \\
\text { mo }\end{array}$ \\
\hline SMREAE & $\begin{array}{l}\text { Ethanol fraction of the } \mathrm{e} \\
\text { mom }\end{array}$ \\
\hline SMLEH & $\begin{array}{c}N \text {-hexane fraction of the ethanol extract of the S. mombin } \\
\text { leaf }\end{array}$ \\
\hline SMLEEA & $\begin{array}{l}\text { Ethyl acetate fraction of the ethanol extract of the } S . \\
\text { mombin leaf }\end{array}$ \\
\hline SMLEE & $\begin{array}{c}\text { Ethanol fraction of the ethanol } \\
\text { leaf }\end{array}$ \\
\hline SMLEAI & $\begin{array}{l}N \text {-hexane fraction of the ethyl acetate extract of the } S . \\
\text { mombin leaf }\end{array}$ \\
\hline SMLEA & $\begin{array}{l}\text { Ethyl acetate fraction of the et } \\
\text { mombir }\end{array}$ \\
\hline SMLE & $\begin{array}{r}\text { Ethanol fraction of the } \\
\text { mo }\end{array}$ \\
\hline SMSB & $N$-hexane fraction of the $\mathrm{e}$ \\
\hline SMSBF & \\
\hline SMSB & Ethanol fraction of the eth \\
\hline SMSBE & $\begin{array}{c}N \text {-hexane fraction of the ethyl acetate extra } \\
\text { mombin stem-bark }\end{array}$ \\
\hline MSBE & $\begin{array}{l}\text { Ethyl acetate fraction of th } \\
\text { mombin }\end{array}$ \\
\hline ISB & $\begin{array}{r}\text { Ethanol fraction of th } \\
\text { mom }\end{array}$ \\
\hline
\end{tabular}

\section{Acknowledgements}

The authors wish to express their appreciation to all the technical staffs of the laboratory unit of both the Department of Microbiology, Faculty of Science, Adekunle Ajasin University, Akungba Akoko, Ondo State, Nigeria and Obafemi Awolowo University, Ile Ife, Osun State, Nigeria for their support and all the technical assistance rendered during the course of this research work.

\section{References}

1. Ayoka AO, Akomolafe RO, Iwalewa EO, Akanma MA, Ukponmwan OE (2006) Sedative, epileptic and antipsychotic effects of Spondias mombin L (Anacardiaceae) in mice and rats. Journal of Ethnopharmacolology 103: 166175 .
2. Rodrigues KF, Hasse M (2000) Antimicrobial activities of secondary metabolites produced by endophytic fungi from Spondias mombin. Journal of Basic Microbiology 40: 261-267.

3. Nworu CS, Akah PA, Okoye FB, Toukam DK, Udeh J, et al. (2011)The lea extract of Spondias mombin L. displays an anti-inflammatory effect and suppresses inducible formation of tumor necrosis factor- $\alpha$ and nitric oxide (NO). Journal Immuno Toxicology 8: 10-16.

4. Villegas LF, Fernández ID, Maldonado H, Torres R, Zavaleta A, et al. (1997) Evaluation of the wound healing activity of selected traditional medicine plants from Peru. Journal of Ethnopharmacology 55: 193-200.

5. Wagner H, Ulrich-Merzenich G (2009) Synergy research: approaching a new generation of phytopharmaceuticals. Phytomedicine 16: 97-110.

6. Baris O, Gulluce M, Sahin F, Ozer H, Kilic H, et al. (2006) Biological activities of the essential oil and methanol extract of Achillea Biebersteinii Afan. (Asteraceae). Turk J Biol 30: 65-73

7. Petrovick PR (1997) Development of new drugs from plant origin. In: World Congress on Medicinal and Aromatic Plants for Human Welfare Abstracts. Mendoza: ICMPA/ISHS/ SAIPOA, p: 21.

8. Williams L, Wilkins S (2007) Textbook of Microbiology. 2nd edn. New Delhi, India: Wolters Kluwer Health Publisher's, pp: 30-31.

9. Ndukwe IG, Amupitan JO, Isah Y, Adegoke KS (2007) Phytochemical and antimicrobial screening of the crude extracts from the root, stem bark and leaves of Vitellaria paradoxa. Afr J Biotechnol 6: 1905-1909.

10. Guevarra BQ (2005) A guidebook to plant screening phytochemical and biological. UST Publishing House, Philippines. In: Hawkins EB, Ehrich SD, Kola G. University of Maryland Medical Center, Baltimore, USA.

11. Ekpo MA, Etim PC (2009) Antimicrobial activity of ethanolic and aqueous extracts of Sida acuta on microorganisms from skin infections. J Med Plant Res 3: 621-624.

12. Azu NC, Onyeagba RA, Okoro N (2007) Antibacterial activity of Allium cepa and Zingiber officinale (Ginger) on Staphylococcus aureus and Pseudomonas aeruginosa Isolated from High Vaginal Swab. The Internet J Trop Med 3: 1-12.

13. Silva-Junior JF, Almeida ER (2013) Collecting, ex situ conservation and characterization of caja'-umbu (Spondias mombin x Spondias tuberosa) germplasm in Pernambuco State, Brazil. Genet Resour Crop Evol 51: 343-349.

14. Soniya M, Kuberan T, Anitha S, Sankareswari $P$ (2013) In vitro antibacteria activity of plant extracts against Gram positive and Gram negative pathogenic bacteria. Int J Microbiology and Immunology Res 2: 1-5.

15. Williams L, Wilkins S (2007) Textbook of Microbiology. 2nd edn. New Delhi, India. Wolters. Kluwer Health Publishers, pp: 30-31.

16. Goyal P, Khanna A, Chauhan G, Kaushik P (2008) In vitro evaluation of crude extracts of Catharanthus roseus for potential antibacterial activity. Int J Green Pharm 2: 176-181.

17. Kirtikar KR, Basu BD (1987) Indian Medicinal Plants. 2nd edn. International Book Distributors, p: 1088.

18. Ahmed F, Selim MST, Shilpi JA (2005) Antibacterial activity of Ludwigia adscendens. Fitoterapia 76: 473-475.

19. Das B, Kundu J, Bachar SC, Uddin MA, Kundu JK (2007) Antitumor and antibacterial activity of ethyl acetate extract of Ludwigia hyssopifolia Linn and its active principle piperine. Pak J Pharmaceut Sci 20: 128-131.

20. Aliyu AB, Musa AM, Abdullahi MS, Oyewale AO (2008) Phytochemical and antibacterial properties of Ludwigia suffruticosa Wild Iliv. Ex. O. Ktze (Onagraceae). Int J Pure Appl Sci 2: 1-5.

21. Osuntokun OT, Olajubu FA (2014) Comparative study of phytochemical and proximate analysis of seven Nigerian medicinal plants. Applied Science Research Journal, Pon Publishers, Ekpoma Edo State, Nigeria 2: 10-26. 